\title{
Checkpoint kinase1 (CHK1) is an important biomarker in breast cancer having a role in chemotherapy response
}

\author{
M M Al-kaabi ${ }^{1,2,7}$, A T Alshareeda ${ }^{1,3,7}$, D A Jerjees ${ }^{1}$, A A Muftah ${ }^{1}$, A R Green ${ }^{1}$, N H Alsubhi ${ }^{1}$, C C Nolan ${ }^{1}$,
} S Chan ${ }^{4}$, E Cornford $^{5}$, S Madhusudan ${ }^{4}$, I O Ellis ${ }^{1,6}$ and E A Rakha ${ }^{*, 1,6}$

${ }^{1}$ Breast Cancer Pathology Research Group, Division of Cancer and Stem Cells, School of Medicine, University of Nottingham, Nottingham University Hospitals NHS Trust, City Hospital, Nottingham NG5 1PB, UK; ${ }^{2}$ Department of Pathology, Faculty of Medicine, Al-Mustansiriya University, Baghdad, Iraq; ${ }^{3}$ Ministry of Higher Education, Riyadh, Saudi Arabia; ${ }^{4}$ Department of Oncology, Division of Cancer and Stem Cells, School of Medicine, University of Nottingham and Nottingham University Hospitals NHS Trust, City Hospital, Nottingham NG5 1PB, UK; ${ }^{5}$ Department of Radiology, Breast Institute, Nottingham University Hospitals NHS Trust, City Hospital, Nottingham NG5 1PB, UK and ${ }^{6}$ Department of Cellular Pathology, The University of Nottingham and Nottingham University Hospitals NHS Trust, Nottingham NG5 1PB, UK

Background: Checkpoint kinase1 (CHK1), which is a key component of DNA-damage-activated checkpoint signalling response, may have a role in breast cancer $(\mathrm{BC})$ pathogenesis and influence response to chemotherapy. This study investigated the clinicopathological significance of phosphorylated CHK1 ( $\mathrm{CCHK1)}$ protein in BC.

Method: PCHK1 protein expression was assessed using immunohistochemistry in a large, well-characterized annotated series of early-stage primary operable invasive BC prepared as tissue microarray $(n=1200)$.

Result: $\mathrm{pCHK1}$ showed nuclear and/or cytoplasmic expression. Tumours with nuclear expression showed positive associations with favourable prognostic features such as lower grade, lower mitotic activity, expression of hormone receptor and lack of expression of KI67 and PI3K ( $P<0.001)$. On the other hand, cytoplasmic expression was associated with features of poor prognosis such as higher grade, triple-negative phenotype and expression of K167, p53, AKT and PI3K. pCHK1 expression showed an association with DNA damage response (ATM, RAD51, BRCA1, KU70/KU80, DNA-PKC $\alpha$ and BARD1) and sumoylation (UBC9 and PIAS $\gamma$ ) biomarkers. Subcellular localisation of PCHK1 was associated with the expression of the nuclear transport protein KPNA2. Positive nuclear expression predicted better survival outcome in patients who did not receive chemotherapy in the whole series and in ER-positive tumours. In ER-negative and triple-negative subgroups, nuclear PCHK1 predicted shorter survival in patients who received cyclophosphamide, methotrexate and 5-florouracil chemotherapy.

Conclusions: Our data suggest that PCHK1 may have prognostic and predictive significance in BC. Subcellular localisation of pCHK1 protein is related to its function.

Systemic therapy targeted at disrupting DNA damage response (DDR) in solid tumours is attracting attention and it is likely to expand in the coming years. A complex series of checkpoint pathways are recognised to have important roles in the repair of any DNA damage (Niida and Nakanishi, 2006). This mechanism is mediated through an array of DDR proteins that when activated are involved in arrest of cell cycle to allow DNA repair process to proceed, thus preventing DNA replication and mitosis in the presence of unrepaired damage; otherwise apoptosis or mutagenesis will occur (Bartek and Lukas, 2003; Dai and Grant, 2010).

*Correspondence: Dr E Rakha; E-mail: emad.rakha@nottingham.ac.uk

${ }^{7}$ These authors contributed equally to this work.

Received 4 May 2014; revised 18 September 2014; accepted 23 September 2014; published online 17 February 2015

(c) 2015 Cancer Research UK. All rights reserved 0007-0920/15 
Following DNA damage, sensor multiprotein complexes activate proximal transducers (that is ATM, ATR), which in turn phosphorylate/activate the distal transducers including serine/ threonine kinase Checkpoint Kinase 1 (CHK1; Walworth et al, 1993; Sanchez et al, 1997; Kaneko et al, 1999; Tse et al, 2007; Zaugg et al, 2007; Dai and Grant, 2010). Phosphorylated CHK1 (pCHK1) is released to activate the effectors (that is, CDC25) causing their sequestration, degradation or phosphorylation. These combined effects will halt the progression of cell cycle at different phases and are referred to as mobile messenger kinases (Kastan and Bartek, 2004; Kramer et al, 2004; Dai and Grant, 2010).

Protein phosphorylation is a well-characterised biochemical process for the reversible regulation of protein activity. In response to DNA damage or replication stress, CHK1 becomes phosphorylated at several C-terminal residues, including the highly conserved S345 and S317 sites (Wilsker et al, 2008; Tapia-Alveal et al, 2009) and this phosphorylation regulates CHK1 intracellular location (Kramer et al, 2004; Loffler et al, 2007; Wilsker et al, 2008). CHK1 appears to function in a cell cycle-dependent manner during at least two phases of the unperturbed cell cycle: $S$ phase and mitosis (Wilsker et al, 2008).

Previous studies have demonstrated that activated $\mathrm{CHK} 1$ and CHK2 phosphorylate a plethora of effectors involved in checkpoints including: effectors that can lead to cell cycle delay (Cdc25A, Cdc25B and p53; Peng et al, 1997; Hirao et al, 2000; Zhao and Piwnica-Worms, 2001), DNA repair (BRCA1 and Rad51; Yarden et al, 2002; Sørensen et al, 2005), induction of apoptosis if the damage is irreparable ( $\mathrm{p} 53$ and E2F1; Ahn et al, 2004) and chromatin remodelling (Tousled like kinase1/2; Groth et al, 2003).

DDR checkpoints can be classified generally into two parallel pathways that respond to diverse types of DNA-damaging agents. In the ATM/ATR-CHK1/CHK2-Cdc5s pathway (for reversible and fast response to DNA damage) CHK 1 is regarded as the key distal transducer. The second pathway is the p53-dependent pathway (for irreversible and slower response). In this pathway CHK1/ CHK2, with ATM/ATR, phosphorylates p53 or Mdm2 to promote p53 stabilisation (Zhou and Bartek, 2004; Dai and Grant, 2010).

Cancer cells use intact DNA repair mechanisms to evade DNA damage induced by chemotherapy or radiotherapy. Therefore, it was hypothesised that using agents that target DDR proteins including checkpoint kinases can enhance the effect of chemotherapy and radiotherapy and decrease resistance of cancer cells to this treatment modality (Verlinden et al, 2007). This approach is expected to be more effective in certain subtypes of cancer such as p53-deficient tumours. In normal cells, p53 induces G1 arrest in response to DNA damage, whereas tumour cells that are often p53-deficient are defective in G1 arrest; therefore, cancer cells, unlike normal cells, rely mainly on S or G2 checkpoints that are mediated by CHK1 (Chen et al, 2006). Currently, CHK1 represents one of the most attractive and potential target for anticancer drug development directed against the DDR network (Dai and Grant, 2010).

The aim of the current study was to investigate the clinical and biological significance of pCHK1 protein expression in $\mathrm{BC}$ with particular attention to its role in $\mathrm{DDR}$ and response to chemotherapy.

\section{MATERIALS AND METHODS}

The current study was conducted using a consecutive series of 1200 primary operable stage I-III invasive BC that were prepared as a tissue microarray (TMA) from formalin-fixed, paraffin-embedded tissue specimens of patients presented to Nottingham Breast Unit between 1988 and 1998. The age of the patients was less than 70 with a median of 55 years (range 18-70) with a tumour size of less than $5 \mathrm{~cm}$ in diameter.
Clinical and pathological data as well as data on a wide range of biomarkers oestrogen receptor (ER)-related genes (ER, progesterone (PgR) and androgen (AR) receptor, GATA3, FOXA1), HER family members (HER1, HER2, HER3 and HER4), DDR proteins (RAD51, BRCA1, BARD1, DNA-PKC $\alpha, \mathrm{KU70/KU80,} \mathrm{UBC9} \mathrm{and}$ ATM), basal (CK5 and CK17) and luminal (CK18) cytokeratin, nuclear transport protein importin subunit alpha-2 (KPNA2; clone Ab84440, Abcam Ltd, Cambridge, UK) used in dilution of $1: 400$ with 60-min incubation; Alshareeda et al, 2014), proliferation and cell cycle-associated proteins (KI67 and p53) and PI3K/AKT pathway proteins (PI3K and AKT) were available. The immunoreactivity, scoring and the optimal cutoff points for these markers were defined as described in the previous studies (Rakha et al, 2006, 2009; Aleskandarany et al, 2011, 2012; Alshareeda et al, 2012, 2013; Agboola et al, 2014).

Data related to outcome including locoregional recurrence, distant metastasis and mortality were collected prospectively. Breast cancer (BC)-specific survival (BCSS) is defined as the time interval in months from the date of the primary surgery until death occurrence due to BC with a median of 129 months (range 4-243 months). Distant metastasis-free survival is defined as duration in months from the primary surgery to the development of distant metastasis with a median of 114 months (range 5-241 months). Patients were managed according to a uniform protocol based on the Nottingham Prognostic Index (NPI) groups, ER and the menopausal status. Patients were offered adjuvant systemic therapy if NPI was >3.4. If NPI was >3.4 and ER-positive, endocrine therapy in form of tamoxifen was given, and if the patient was premenopausal Zoladex was added to the previous protocol. A systemic chemotherapy regimen of cyclophosphamide, methotrexate and 5-florouracil (CMF) was used if the patient was ERnegative, provided that the patient was considered fit enough to withstand this regimen. In this series, $25 \%$ received chemotherapy and $45 \%$ received hormone therapy. None of the patients received anti-HER2-targeted therapy or neoadjuvant therapy.

Immunohistochemistry method. The expression of pCHK1 was investigated in breast tumours using TMA prepared using $0.6-\mathrm{mm}$ cores. Freshly cut $4-\mu \mathrm{m}$ sections of the TMA were stained using pCHK1 antibody (CHK1phospho-S345; AbCam clone Ab 58567), which is the commonly used biomarker of Chk1 activation (Wilsker et al, 2008). At first, the slides were heated on a hot plate to $60^{\circ} \mathrm{C}$ for $10 \mathrm{~min}$ and then deparaffinised in xylene twice for $5 \mathrm{~min}$ each. The slides were rehydrated in descending alcohol concentrations and then in water for $5 \mathrm{~min}$. Antigen retrieval was performed by incubating slides in retrieval solution of citrate buffer, $\mathrm{pH}$ 6, for $20 \mathrm{~min}$ using a microwave. The slides were cooled in cold tap water for $5 \mathrm{~min}$. The immunohistochemical staining was performed using Novocastra Novolink polymer detection kit system (Leica Microsystem, Newcastle, UK) according to the manufacturer's instructions. Briefly, hydrogen peroxide was added to block the endogenous peroxidase activity to decrease unwanted background staining. The primary antibody was added at optimum dilution $(1: 150)$ and incubated for $1 \mathrm{~h}$. After washing the slides, the polymer link was incubated for $30 \mathrm{~min}$. DAB was added for $5 \mathrm{~min}$. Haematoxylin was used as a counterstain for $5 \mathrm{~min}$ followed by rinsing in tap water. Finally, the slides were dehydrated in alcohol, cleared in xylene and then cover-slipped using DPX (BDH, Poole, UK).

Scoring of CHK1 in TMA core slides. Assessment of pCHK1 expression was conducted using a web-based interface (Distiller, Slide path Ltd, Dublin, Ireland) after high-resolution digital-image virtual slides of the stained TMA slides were prepared at $\times 20$ magnification using NanoZoomer (Hamamatsu Photonics, Welwyn Garden City, UK). The scoring method was semiquantitative using a modified histochemical score $(H$-score) that includes both the percentage of the stained cells and the staining intensity. 
The intensity of staining was scored on a scale of $0-3$, where the $(0)$ was referred to negative, (1) referred to weak, whereas the moderate cases were scored as (2) and the strong were scored as (3). Visual estimation was used to determine the percentage of positive cells. The final score is achieved by multiplication of 2 indices and the results range from 0 to 300 . Records of $\mathrm{pCHK} 1$ expression pattern were visually estimated as nuclear, cytoplasmic or combined nuclear and cytoplasmic staining. The scoring was carried on without previous knowledge of clinical data. Cores with invasive tumours less than $15 \%$ were excluded.

Statistical analysis. Statistical analysis was performed by using the SPSS IBM 21 statistical software (IBM, New York, NY). The relationship between $\mathrm{pCHK} 1$ and different clinicopathological variables was assessed using $\chi^{2}$-test for categorical data and MannWhitney $U$-test for continuous variables. Survival curves were obtained using Kaplan-Meier method for outcome estimation and significance determined using the log-rank test. Multivariate survival analysis was performed using Cox hazard regression model including established prognostic variables significant on univariate analysis. Two-tailed $P$-value less than 0.01 was considered significant in view of multiple comparisons.

\section{RESULTS}

Of the whole series, 1079 (90\%) cases had sufficient cores to perform scoring. The expression of pCHK1 was detected in the nuclei and cytoplasm of the neoplastic cells (Figure 1). Nuclear pCHK1 expression was detected in $50 \%$ of cases $(>0 \%)$ and had a median $H$-score of 29 (range $0-300$ ), whereas cytoplasmic pCHK1 was detected in $94 \%(>0 \%)$ and had a median $H$-score of 200 (range 0-300). There was a correlation between nuclear and cytoplasmic expression $(P<0.0001)$. For statistical analysis, expression was dichotomised using cutoff points that were selected based on histogram distribution and by the X-tile computer software analysis (Camp et al, 2004) that dichotomises marker expression according to association with outcome. The cutoff points were selected as follows: for nuclear pCHK1, an $H$-score of 20 with 791 out of 1079 (73\%) of the cases showing negative/low nuclear expression and for cytoplasmic pCHK1 expression $H$-score of 80 was used with 128 out of 1079 (12\%) of the cases showing negative/low expression.

Association with clinicopathological parameters. Higher nuclear pCHK1 immunohistochemical expression was associated with markers of good prognosis including lower grade with a low proliferation status, smaller size, good NPI and expression of oestrogen receptor-related proteins (ER, PgR, AR, GATA3 and FOXA1). Negative association was seen with triple-negative phenotype and tumours expressing high ki67-labelling index $(\mathrm{Ki67LI})$ and PI3K $(P<0.0001)$. Conversely, cytoplasmic pCHK1 was associated with higher grade with a high proliferation status, poor NPI and lack of expression of ER and PgR. There was a positive association between cytoplasmic expression and triplenegative phenotype, Ki67LI and p53, CK5, AKT and PI3K expression (Tables 1 and 2).

Strong correlation was observed between pCHK1 expression with other DDR proteins. There was a positive association between nuclear pCHK1 and expression of homologous recombination (ATM, RAD51 and BRCA1) and sumoylation (PIAS $\gamma$ and nuclear UBC9) markers. Negative association of borderline significance $(P=0.037)$ was identified with ATR. Cytoplasmic pCHK1 expression was positively associated with the expression of nonhomologous end-joining markers (KU70/KU80, PIAS $\gamma$, DNA-PKC $\alpha$ and cytoplasmic UBC9) and with the cytoplasmic homologous recombination marker BARD1 (Table 2).
Regarding subcellular localisation of pCHK1, there was an association between the nuclear transport protein KPNA2 and cytoplasmic/nuclear expression pCHK1. Positive KPNA2 expression was associated with cytoplasmic localisation of the pCHK1 with reduced/negative nuclear expression (nuclear-negative/ cytoplasmic-positive phenotype), whereas absence of KPNA2 protein was associated with the lack of cytoplasmic pCHK1 localisation (cytoplasmic negative/nuclear-positive or -negative phenotypes (Table 3).

Relationship with clinical outcome. In the whole series, high expression of nuclear pCHK1 showed an association of borderline significance with longer BCSS $(P=0.018$ at 5 years and $P=0.030$ at 15 years of survival). Conversely, high expression of cytoplasmic pCHK1 was associated with shorter BCSS $(P=0.009$ at 5 years and $P=0.024$ at 15 years of survival) as shown in Figure 2. However, multivariate Cox regression analysis including potential confounding factors of (tumour size, grade, stage, ER and therapy) showed that neither nuclear nor cytoplasmic pCHK1 expression were independent predictors of BCSS $(P=0.551$ and $P=0.344$, respectively). Association with distant metastasis-free interval was not significant $(P=0.221$ and $P=0.324$ for nuclear and cytoplasmic pCHK1, respectively); the data are not shown.

When the cohort was stratified with respect to chemotherapy, a significant association between positive nuclear pCHK1 expression and longer BCSS was found in the subgroup of patients who did not receive chemotherapy $(P=0.014)$, whereas for those receiving chemotherapy there was no statistical difference $(P=0.351$; Figure 3). Further stratification according to the ER status revealed that similar associations were maintained in the ER-positive subgroup with an association between nuclear pCHK1 expression and longer BCSS in chemotherapy-naive patients $\left(\chi^{2}=10.1\right.$, $P=0.001)$ and no association in chemotherapy-treated patients. Interestingly, in the ER-negative subgroup, the opposite was identified; no association with outcome was observed in chemotherapy-naive patients, whereas among the patients who received chemotherapy longer BCSS was seen in those whose tumours lacked nuclear pCHK1 $\left(\chi^{2}=5.4, P=0.021\right)$. When triplenegative tumours were selected, an association between the lack of nuclear pCHK1 and better outcome in chemotherapy-treated subgroup was also obtained $(P=0.043$; Figure 4$)$.

$P$-interaction between $\mathrm{pCHK} 1$ and chemotherapy was positive in the whole series $(P=0.012(\mathrm{HR}=2.4$ and $95 \% \mathrm{CI}=1.2-4.7))$. When stratified according to ER, $P$-interaction was significant in the ER-negative subgroup $(P=0.026(\mathrm{HR}=2.8$ and $95 \% \mathrm{CI}=1.1-$ $7.1))$ but not in the ER-positive subgroup $(P=0.226)$.

Regarding cytoplasmic CHK1, lack of expression showed borderline significance with better BCSS in patients who did not receive chemotherapy $(P=0.027)$ but not in those who received chemotherapy $(P=0.816$; Figure 3$)$.

\section{DISCUSSION}

DNA damage is a ubiquitous process, occurring in all nucleated normal cells and, to a higher degree, in neoplastic cells. Sensing of DNA damage is mediated through several distinct complexes of proteins, which are determined by the nature of the DNA lesions and act to catalyse repair (Dai and Grant, 2010). Formation of repair complexes initiates signalling processes that lead to cell cycle arrest to allow DNA repair without the occurrence of additional DNA replication or cell division. CHK1 is an important protein involved in cell cycle control during DDR and is proposed to be a potential marker that can influence the response of proliferating tumour cells to chemotherapies that damage DNA. In addition, CHK1 inhibitors have emerged as promising novel therapeutic agents (Thompson and Eastman, 2013). 

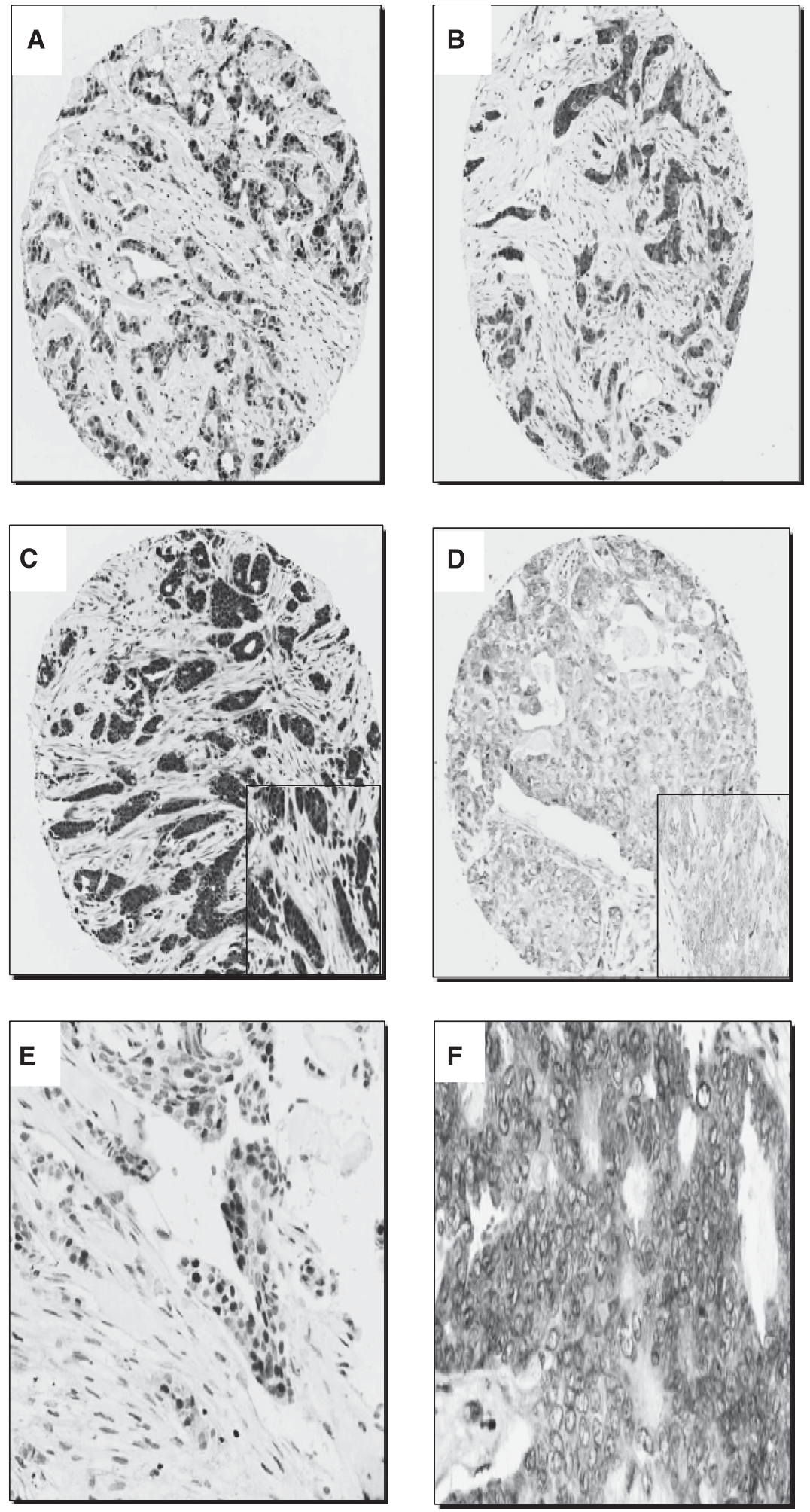

Figure 1. Immunohistochemical expression of CHK1 at $\times 20$. CHK1 immunostaining for both nuclear and cytoplasmic in $\mathbf{A}-\mathbf{C}$, whereas in $\mathbf{D}$ there is weak cytoplasmic staining; the inset refers to the high power. Panel $\mathbf{E}$ demonstrates only nuclear pCHK1 expression, whereas exclusive cytoplasmic PCHK1 expression appears in $\mathbf{F}$.

This study aimed to investigate pCHK1 protein expression in $\mathrm{BC}$ to further understand its role in DDR and whether it is associated with tumour chemotherapy response and therefore could influence patients' outcome. The expression of pCHK1 was detected in the nucleus and/or in the cytoplasm of the malignant cells. This different subcellular localisation correlated differently with clinicopathological parameters and patients' outcome. Our results demonstrate that the tumours expressing nuclear $\mathrm{pCHK} 1$ feature variables associated with good prognosis including lower grade, lower proliferation status and positivity for hormone receptors. In addition, they express other processes involved in DNA-damage-sensing and homologous recombination DNAdamage repair mechanisms (ATM, RAD51 and BRCA1) and related sumoylation proteins (UBC9 and PIAS $\gamma$ ). Downregulation 
Table 1. Association between nuclear and cytoplasmic CHK1 expression and clinicopathological parameters

Nuclear expression

Cytoplasmic expression

\begin{tabular}{|c|c|c|c|c|c|c|}
\hline Clinicopathological variables & Neg./low (\%; <20) & High $(\% \geqslant 20)$ & $P$-value & Neg./low (\%; <80) & High $(\% ; \geqslant 80)$ & $P$-value \\
\hline \multicolumn{7}{|l|}{ Age } \\
\hline $\begin{array}{l}<50 \\
\geqslant 50\end{array}$ & $\begin{array}{l}263(33) \\
528(67)\end{array}$ & $\begin{array}{r}95(33) \\
193(67)\end{array}$ & 0.935 & $\begin{array}{l}41(32) \\
87(68)\end{array}$ & $\begin{array}{l}317(33) \\
633(67)\end{array}$ & 0.763 \\
\hline \multicolumn{7}{|l|}{ Menopause } \\
\hline $\begin{array}{l}\text { Pre } \\
\text { Post }\end{array}$ & $\begin{array}{l}288(37) \\
502(63)\end{array}$ & $\begin{array}{l}112(39) \\
176(61)\end{array}$ & 0.464 & $\begin{array}{l}45(35) \\
83(65)\end{array}$ & $\begin{array}{l}355(37) \\
594(63)\end{array}$ & 0.621 \\
\hline \multicolumn{7}{|l|}{ Size } \\
\hline $\begin{array}{l}<1.5 \mathrm{~cm} \\
>1.5 \mathrm{~cm}\end{array}$ & $\begin{array}{l}369(47) \\
417(53)\end{array}$ & $\begin{array}{l}157(55) \\
131(45)\end{array}$ & 0.028 & $\begin{array}{l}66(52) \\
61(48)\end{array}$ & $\begin{array}{l}460(49) \\
486(51)\end{array}$ & 0.479 \\
\hline \multicolumn{7}{|l|}{ Lymph node stage } \\
\hline $\begin{array}{l}1 \\
2 \\
3 \\
\end{array}$ & $\begin{array}{c}414(58) \\
244(34) \\
54(8)\end{array}$ & $\begin{array}{r}156(64) \\
75(31) \\
13(5)\end{array}$ & 0.221 & $\begin{array}{c}67(62) \\
34(31) \\
7(7)\end{array}$ & $\begin{array}{c}502(59) \\
285(34) \\
60(7)\end{array}$ & 0.858 \\
\hline \multicolumn{7}{|l|}{ Grade } \\
\hline $\begin{array}{l}1 \\
2 \\
3\end{array}$ & $\begin{array}{r}95(12) \\
255(33) \\
434(55)\end{array}$ & $\begin{array}{r}73(26) \\
107(37) \\
107(37)\end{array}$ & $<0.0001$ & $\begin{array}{l}26(20) \\
61(48) \\
40(32)\end{array}$ & $\begin{array}{l}142(15) \\
301(32) \\
500(53)\end{array}$ & $<0.0001$ \\
\hline \multicolumn{7}{|l|}{ Mitotic count } \\
\hline $\begin{array}{l}1 \\
2 \\
3\end{array}$ & $\begin{array}{l}226(30) \\
149(20) \\
384(51)\end{array}$ & $\begin{array}{r}120(44) \\
58(20) \\
98(36)\end{array}$ & $<0.0001$ & $\begin{array}{ll}61 & (50) \\
21 & (17) \\
41 & (33) \\
\end{array}$ & $\begin{array}{l}285(31) \\
186(21) \\
440(48)\end{array}$ & $<0.0001$ \\
\hline \multicolumn{7}{|l|}{ Stage } \\
\hline $\begin{array}{l}1 \\
2 \\
3\end{array}$ & $\begin{array}{c}456(58) \\
256(33) \\
73(9)\end{array}$ & $\begin{array}{c}189(66) \\
79(28) \\
19(6)\end{array}$ & 0.061 & $\begin{array}{l}84(65) \\
34(27) \\
10(8)\end{array}$ & $\begin{array}{c}560(59) \\
301(32) \\
82(9)\end{array}$ & 0.393 \\
\hline \multicolumn{7}{|l|}{ NPI } \\
\hline $\begin{array}{l}\text { Good } \\
\text { Moderate } \\
\text { Poor }\end{array}$ & $\begin{array}{l}194(26) \\
432(58) \\
123(16)\end{array}$ & $\begin{array}{r}121(45) \\
121(45) \\
29(10) \\
\end{array}$ & $<0.0001$ & $\begin{array}{l}50(42) \\
54(46) \\
14(12)\end{array}$ & $\begin{array}{l}265(30) \\
498(55) \\
138(15)\end{array}$ & 0.016 \\
\hline \multicolumn{7}{|l|}{ LVI } \\
\hline $\begin{array}{l}\text { Negative } \\
\text { Positive }\end{array}$ & $\begin{array}{l}505(64) \\
279(36) \\
\end{array}$ & $\begin{array}{r}196(68) \\
91(32) \\
\end{array}$ & 0.237 & $\begin{array}{l}85(67) \\
42(33) \\
\end{array}$ & $\begin{array}{l}615(65) \\
328(35) \\
\end{array}$ & 0.703 \\
\hline
\end{tabular}

of pCHK1 expression was seen more frequently in tumours with high proliferation status, positive for PI3K and HER2 and in those showing triple-negative phenotype. In contrast, cytoplasmic expression is associated with variables characteristic of poor prognosis including higher grade, high proliferation status, lack of hormone receptors and triple-negative phenotype. Cytoplasmic pCHK1 was associated with non-homologous end-joining markers (KU70/KU80 and DNA-PKC $\alpha$ ) and with cytoplasmic expression of the homologous recombination (BARD1) and the related sumoylation (UBC9) proteins. Combinatorial expression of nuclear and cytoplasmic expression of pCHK1 revealed that association with good prognostic variables and DDR markers was positive in pure nuclear expression, intermediate in double-negative cases and negative in cases with pure cytoplasmic expression (data not shown). These results may indicate that the cytoplasmic CHK1 protein in $\mathrm{BC}$ tissue is not just a form of an aberrant/nonfunctional protein but a protein that may have a function contrasting with that of the functionally normal nuclear localisation of the $\mathrm{pCHK} 1$ protein (Wang et al, 2012).

Using immunoblotting and subcellular fractionation techniques, Niida et al (2007) have detected CHK1 in both the cytoplasm and the nucleus at almost the same level, although its expression is decreased in the cytoplasm in the late $S$ phase. They have found that pCHK1 at S317 is predominantly cytoplasmic in the early $\mathrm{S}$ phase and nuclear in the late $S$ phase, whereas the expression of CHK1 phosphorylated at S345 is detected only in the cytoplasmic fraction. The findings of these authors and others (Wilsker et al, 2008) indicate that not only phosphorylation status but also phosphorylation site can affect subcellular localisation of CHK1. Niida et al (2007) suggested that pCHK1 at S345, but not at S317, might be important for cytoplasmic localisation of Chk1 during the $S$ phase and that the mobility shift in CHK1, upon DNA damage, was observed only in the cytoplasm and the phosphorylation is critical for signal transducing to downstream target. In fission yeast it was reported that phosphorylation of $\mathrm{CHK} 1$ at ser345 appears to be required for checkpoint function, and this phosphorylation increases the pCHK1 in the nucleus through interaction with 14-33 protein (Dunaway et al, 2005). It was also hypothesised that the cytoplasmic expression of CHK1 may have a role in tumorigenesis through the DNA damage sensors and as a transducer for signal pathway, and take this action as a pathway for tumour survival (Bartek and Lukas, 2003; Harper and Elledge, 2007); however, further studies are needed to confirm this hypothesis.

The subcellular localisation of $\mathrm{CHK} 1$ and the association between aggressive behaviour of cytoplasmic CHK1 in this study may be explained by a defective function of CHK1 in BC. Puc et al (2005) used a mouse mammary tumour model to study the effect of cytoplasmic $\mathrm{CHK} 1$ on genomic instability. They revealed that, at the G2 phase of the cell cycle, CHK1 observed to leave from the nucleus at the time of AKT kinase phosphorylation peak and the reduction of nuclear CHK1 could be explained by the raise of Cdc25A protein noticed in the G2/M phase (Bernardi et al, 2000). 
Table 2. Associations between CHK1 and different proteins

Nuclear CHK1 expression

Cytoplasmic CHK1 expression

\begin{tabular}{|c|c|c|c|c|c|c|}
\hline Biomarkers & $\begin{array}{c}\text { Neg./low } \\
\text { expression } \\
\text { no. (\%) }\end{array}$ & $\begin{array}{c}\text { High expression } \\
\text { no. (\%) }\end{array}$ & $P$-value & $\begin{array}{c}\text { Neg./low expression } \\
\text { no. (\%) }\end{array}$ & $\begin{array}{c}\text { Positive expression } \\
\text { no. (\%) }\end{array}$ & $P$-value \\
\hline \multicolumn{7}{|c|}{ Oestrogen receptor (ER)-related proteins } \\
\hline $\begin{array}{l}\text { ER } \\
\text { NEG } \\
\text { POS }\end{array}$ & $\begin{array}{l}230(29) \\
556(71)\end{array}$ & $\begin{array}{r}45(16) \\
241(84)\end{array}$ & $<0.0001$ & $\begin{array}{r}14(11) \\
114(89)\end{array}$ & $\begin{array}{l}266(28) \\
683(72)\end{array}$ & $<0.0001$ \\
\hline $\begin{array}{l}\text { PgR } \\
\text { NEG } \\
\text { POS }\end{array}$ & $\begin{array}{l}346(45) \\
426(55)\end{array}$ & $\begin{array}{l}86(31) \\
190(9)\end{array}$ & $<0.0001$ & $\begin{array}{l}36(29) \\
90(71)\end{array}$ & $\begin{array}{l}395(43) \\
526(57)\end{array}$ & 0.002 \\
\hline $\begin{array}{l}\text { AR } \\
\text { NEG } \\
\text { POS }\end{array}$ & $\begin{array}{l}287(40) \\
424(60)\end{array}$ & $\begin{array}{r}72(28) \\
186(72)\end{array}$ & $<0.0001$ & $\begin{array}{l}35(31) \\
79(69)\end{array}$ & $\begin{array}{l}323(38) \\
531(62)\end{array}$ & 0.149 \\
\hline $\begin{array}{l}\text { GATA3 } \\
\text { NEG } \\
\text { POS }\end{array}$ & $\begin{array}{l}389(72) \\
151(28)\end{array}$ & $\begin{array}{l}80(49) \\
83(51)\end{array}$ & $<0.0001$ & $\begin{array}{l}63(76) \\
20(24)\end{array}$ & $\begin{array}{l}405(65) \\
214(35)\end{array}$ & 0.057 \\
\hline $\begin{array}{l}\text { FOXA1 } \\
\text { NEG } \\
\text { POS }\end{array}$ & $\begin{array}{l}373(68) \\
174(32)\end{array}$ & $\begin{array}{r}68(35) \\
125(65)\end{array}$ & $<0.0001$ & $\begin{array}{l}34(38) \\
55(62)\end{array}$ & $\begin{array}{l}407(63) \\
243(37)\end{array}$ & $<0.0001$ \\
\hline
\end{tabular}

\section{HER family proteins}

HER2

NEG

POS

NEG

POS

HER3
NEG

POS

HER4

NEG

Triple-negative (TN)

Non-TN

TN

(

DNA repair proteins

ATM

NEG

POS

ATR
NEG

ROS

NEG

POS

BRCA1

NEG

POS

$174(32)$

125 (65)

$243(37)$

\begin{tabular}{|c|c|c|}
\hline $\begin{array}{l}658(86) \\
110(14)\end{array}$ & $\begin{array}{c}254(91) \\
26(9)\end{array}$ & 0.032 \\
\hline $\begin{array}{r}1620(80) \\
159(20)\end{array}$ & $\begin{array}{r}230(81) \\
53(19)\end{array}$ & 0.544 \\
\hline $\begin{array}{c}44(6) \\
685(94)\end{array}$ & $\begin{array}{r}37(14) \\
222(86)\end{array}$ & $<0.0001$ \\
\hline $\begin{array}{r}75(10) \\
696(90)\end{array}$ & $\begin{array}{r}53(19) \\
225(81)\end{array}$ & $<0.0001$ \\
\hline $\begin{array}{l}614(79) \\
160(21)\end{array}$ & $\begin{array}{r}251(90) \\
28(10)\end{array}$ & $<0.0001$ \\
\hline
\end{tabular}

\begin{tabular}{|c|c|c|}
\hline $\begin{array}{l}658(86) \\
110(14)\end{array}$ & $\begin{array}{c}254(91) \\
26(9)\end{array}$ & 0.032 \\
\hline $\begin{array}{r}1620(80) \\
159(20)\end{array}$ & $\begin{array}{r}230(81) \\
53(19)\end{array}$ & 0.544 \\
\hline $\begin{array}{c}44(6) \\
685(94)\end{array}$ & $\begin{array}{r}37(14) \\
222(86)\end{array}$ & $<0.0001$ \\
\hline $\begin{array}{r}75(10) \\
696(90)\end{array}$ & $\begin{array}{r}53(19) \\
225(81)\end{array}$ & $<0.0001$ \\
\hline $\begin{array}{l}614(79) \\
160(21)\end{array}$ & $\begin{array}{r}251(90) \\
28(10)\end{array}$ & $<0.0001$ \\
\hline
\end{tabular}

$111(90)$
$12(10)$
$106(84)$
$20(16)$
$12(11)$
$99(89)$
$26(22)$
$95(79)$
$115(90)$
$12(10)$

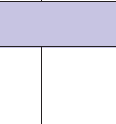

$800(87)$
$124(13)$
$744(80)$
$191(20)$
$69(8)$
$807(92)$
$102(11)$
$825(89)$
$750(81)$
$175(19)$

0.256

\begin{tabular}{|c|c|c|c|}
\hline 257 (39) & $135(56)$ & & $34(43)$ \\
\hline $\begin{array}{l}267(8) \\
195(42)\end{array}$ & $\begin{array}{r}110(67) \\
54(33)\end{array}$ & 0.037 & $\begin{array}{l}45(85) \\
32(42)\end{array}$ \\
\hline $\begin{array}{l}426(63) \\
147(37)\end{array}$ & $\begin{array}{l}65(46) \\
75(54)\end{array}$ & 0.001 & $\begin{array}{c}44(68) \\
21(32)\end{array}$ \\
\hline $\begin{array}{l}128(20) \\
513(80)\end{array}$ & $\begin{array}{r}26(12) \\
199(88)\end{array}$ & 0.005 & $\begin{array}{l}16(17) \\
80(83)\end{array}$ \\
\hline $\begin{array}{r}64(12) \\
475(80)\end{array}$ & $\begin{array}{r}23(12) \\
162(88)\end{array}$ & 0.896 & $\begin{array}{l}22(28) \\
58(72)\end{array}$ \\
\hline $\begin{array}{l}212(25) \\
641(75)\end{array}$ & $\begin{array}{r}47(16) \\
245(84)\end{array}$ & 0.002 & $\begin{array}{l}43(36) \\
75(64)\end{array}$ \\
\hline $\begin{array}{l}113(13) \\
766(87)\end{array}$ & $\begin{array}{r}41(14) \\
254(86)\end{array}$ & 0.690 & $\begin{array}{l}40(33) \\
83(67)\end{array}$ \\
\hline $\begin{array}{l}100(15) \\
553(85)\end{array}$ & $\begin{array}{r}29(13) \\
186(87)\end{array}$ & 0.581 & $\begin{array}{l}26(33) \\
53(67)\end{array}$ \\
\hline $\begin{array}{l}387(55) \\
312(45)\end{array}$ & $\begin{array}{r}97(42) \\
136(58)\end{array}$ & $<0.0001$ & $\begin{array}{l}50(58) \\
36(42)\end{array}$ \\
\hline $\begin{array}{l}373(36) \\
486(64)\end{array}$ & $\begin{array}{r}66(38) \\
108(62)\end{array}$ & 0.662 & $\begin{array}{l}51(58) \\
35(42)\end{array}$ \\
\hline
\end{tabular}

\begin{tabular}{|c|c|}
\hline $\begin{array}{l}455(65) \\
358(44)\end{array}$ & 0.865 \\
\hline $\begin{array}{l}332(61) \\
216(39)\end{array}$ & 0.719 \\
\hline $\begin{array}{l}267(57) \\
200(43)\end{array}$ & 0.107 \\
\hline $\begin{array}{l}138(18) \\
631(82)\end{array}$ & 0.757 \\
\hline $\begin{array}{r}65(10) \\
578(90)\end{array}$ & $<0.0001$ \\
\hline $\begin{array}{l}216(21) \\
810(79)\end{array}$ & $<0.0001$ \\
\hline $\begin{array}{l}114(11) \\
936(99)\end{array}$ & $<0.0001$ \\
\hline $\begin{array}{l}103(13) \\
685(87)\end{array}$ & $<0.0001$ \\
\hline $\begin{array}{l}434(51) \\
411(49)\end{array}$ & 0.258 \\
\hline $\begin{array}{l}288(34) \\
558(66)\end{array}$ & $<0.0001$ \\
\hline
\end{tabular}




\begin{tabular}{|c|c|c|c|c|c|c|}
\hline \multirow[b]{2}{*}{ Biomarkers } & \multicolumn{3}{|c|}{ Nuclear CHK1 expression } & \multicolumn{3}{|c|}{ Cytoplasmic CHK1 expression } \\
\hline & $\begin{array}{c}\text { Neg./low } \\
\text { expression } \\
\text { no. (\%) }\end{array}$ & $\begin{array}{l}\text { High expression } \\
\text { no. (\%) }\end{array}$ & $P$-value & $\begin{array}{c}\text { Neg./low expression } \\
\text { no. (\%) }\end{array}$ & $\begin{array}{c}\text { Positive expression } \\
\text { no. (\%) }\end{array}$ & $P$-value \\
\hline \multicolumn{7}{|c|}{ Cytokeratins (CK) } \\
\hline $\begin{array}{l}\text { CK5 } \\
\text { NEG } \\
\text { POS }\end{array}$ & $\begin{array}{l}259(74) \\
208(26)\end{array}$ & $\begin{array}{r}198(78) \\
56(22)\end{array}$ & 0213 & $\begin{array}{c}87(93) \\
7(7)\end{array}$ & $\begin{array}{l}702(73) \\
256(27)\end{array}$ & $<0.0001$ \\
\hline $\begin{array}{c}\text { CK17 } \\
\text { NEG } \\
\text { POS }\end{array}$ & $\begin{array}{r}519(86) \\
88(15)\end{array}$ & $\begin{array}{r}180(90) \\
19(10)\end{array}$ & 0.074 & $\begin{array}{l}74(94) \\
5(6)\end{array}$ & $\begin{array}{l}625(86) \\
101(14)\end{array}$ & 0.058 \\
\hline $\begin{array}{c}\text { CK18 } \\
\text { NEG } \\
\text { POS }\end{array}$ & $\begin{array}{l}111(16) \\
603(85)\end{array}$ & $\begin{array}{c}23(9) \\
232(91)\end{array}$ & 0.010 & $\begin{array}{l}12(11) \\
96(89)\end{array}$ & $\begin{array}{l}121(14) \\
739(86)\end{array}$ & 0.400 \\
\hline \multicolumn{7}{|c|}{ Tumour suppressor, signalling and proliferation-associated proteins } \\
\hline $\begin{array}{l}\text { p53 } \\
\text { NEG } \\
\text { POS }\end{array}$ & $\begin{array}{l}544(71) \\
226(29)\end{array}$ & $\begin{array}{r}208(74) \\
72(26)\end{array}$ & 0.248 & $\begin{array}{r}106(85) \\
19(15)\end{array}$ & $\begin{array}{l}645(80) \\
279(30)\end{array}$ & $<0.0001$ \\
\hline $\begin{array}{c}\text { KI67 } \\
\text { NEG } \\
\text { POS }\end{array}$ & $\begin{array}{l}116(50.9) \\
112(49.1)\end{array}$ & $\begin{array}{l}59(56.7) \\
45(43.3)\end{array}$ & $<0.0001$ & $\begin{array}{l}61(54) \\
53(46)\end{array}$ & $\begin{array}{l}335(34) \\
659(66)\end{array}$ & $<0.0001$ \\
\hline $\begin{array}{l}\text { Akt } \\
\text { NEG } \\
\text { POS }\end{array}$ & $\begin{array}{l}131(22) \\
458(78)\end{array}$ & $\begin{array}{r}51(28) \\
134(72)\end{array}$ & 0.137 & $\begin{array}{l}36(40) \\
55(60)\end{array}$ & $\begin{array}{l}146(21) \\
537(79)\end{array}$ & $<0.0001$ \\
\hline $\begin{array}{c}\text { PI3K } \\
\text { NEG } \\
\text { POS }\end{array}$ & $\begin{array}{l}146(22) \\
510(78)\end{array}$ & $\begin{array}{l}66(28) \\
16472)\end{array}$ & 0.003 & $\begin{array}{l}37(34) \\
73(66)\end{array}$ & $\begin{array}{l}175(23) \\
600(77)\end{array}$ & 0.001 \\
\hline
\end{tabular}

Table 3. The association between KPNA2 expression and CHK1 subcellular localisation

CHK1 nuclear and cytoplasmic expression Number of cases (\%)

\begin{tabular}{|l|c|c|c|c|}
\hline KPNA2 & Nuc - /cyto - & Nuc + /cyto - & Nuc - /cyto + & Nuc + /cyto + \\
\hline KPNA2 negative & $37(72)$ & $19(73)$ & $225(49)$ & $94(68)$ \\
\hline KPNA2 positive & $14(28)$ & $7(27)$ & $233(51)$ & $45(32)$ \\
\hline Abbreviations: CHK1 = checkpoint kinase1; cyto = cytoplasmic; KPNA2 = karyopherin alpha 2; Nuc= nuclear. & \\
\hline
\end{tabular}

Another possible explanation is that sequestration of cytoplasmic pCHK1 occurs in genomically unstable cells such as PTENdeficient cells. Puc et al (2005) have provided evidence that primary BC cells lacking PTEN expression have increased AKT phosphorylation, elevated cytoplasmic $\mathrm{CHK} 1$, reduced nuclear location and structural and numerical chromosomal alterations. Therefore, this accumulated cytoplasmic CHK1 occurs in genetically unstable cells that lack an essential tumour suppressor gene (Shen et al, 2007; Yin and Shen, 2008) that protects the genome stability, hence it is associated with aggressive behaviour tumours, whereas the nuclear type usually occurs in genetically stable cells. In addition, activation of CHK1 occurs in the nucleus; therefore, this nuclear accumulation seems to be of a great importance in the preparation for functional DDR (Goto et al, 2012).

Interestingly, the association between subcellular localisation of $\mathrm{CHK} 1$ and the nuclear transport protein KPNA2 may indicate an active process and not just sequestration of an aberrant protein into the cytoplasm. However, these observations are best interpreted when considering the in vitro functional studies of the CHK1 protein (see below).

Several studies have investigated CHK1 in BC cell lines, but only a few have investigated CHK1 protein expression in human breast carcinoma. Most of the previous studies used the total CHK1 protein and not the phosphorylated forms. Verlinden et al (2007) showed that CHK1 expression was higher in high-grade triplenegative cases. High CHK1 transcript level was associated with tumours of large size, high histological grade and low/absent ER and PgR; however, they did not find a significant association with HER2 or lymph node metastasis. Other authors have demonstrated that high CHK1 expression was positively associated with highgrade and high ki67 level, positive lymph nodes and large tumour size and have regarded CHK1 as a marker of aggressiveness (Lundgren et al, 2008). However, most of the studies of CHK1 expression in human $\mathrm{BC}$ did not consider the phosphorylated form or subcellular localisation of this protein. The exact molecular mechanism that mediates subcellular localisation of the CHK1 protein in $\mathrm{BC}$ remains unclear. Some authors suggest that there is continuous shuttling of CHK1 occurring both under normal growth condition (Enomoto et al, 2009; Goto et al, 2012; Xu et al, 2012) and in response to DNA damage (Dunaway et al, 2005; Zhang et al, 2005; Smits et al, 2006). Under normal growth conditions, CHK1 expression is mainly located in the nucleus (Wang et al, 2012) during the interphase from G1 to G2 phase (Goto et al, 2012). It is also proposed that the phosphorylation of $\mathrm{CHK} 1$ by $\mathrm{CdK} 1$ is at a site distinct from that activated by ATR (Ser286, Ser301) and triggers Crm-1-dependent nuclear export of $\mathrm{CHK} 1$ to mediate cell cycle transition of $\mathrm{G} 2 / \mathrm{M}$ phase (Enomoto et al, 2009). Others propose that activation of CHK1 by 

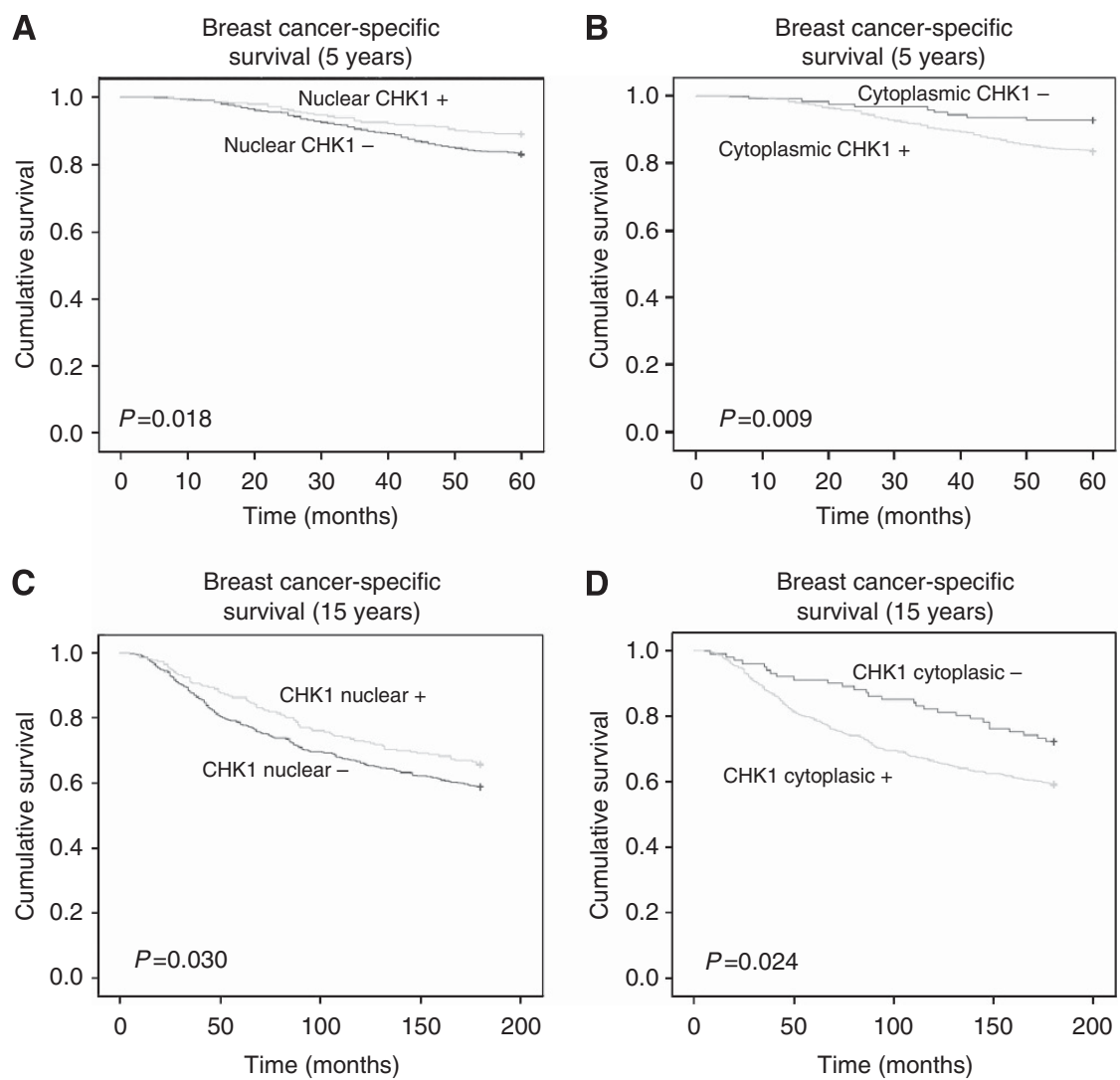

Figure 2. pCHK1 subcellular localisation and outcome. Kaplan-Meier curve of nuclear (A) and cytoplasmic (B) pCHK1 expression in the whole series of breast cancer patients with respect to BCSS for 5 years. Kaplan-Meier curve of nuclear (C) and cytoplasmic (D) pCHK1 expression in the whole series of breast cancer patients with respect to BCSS for 15 years.
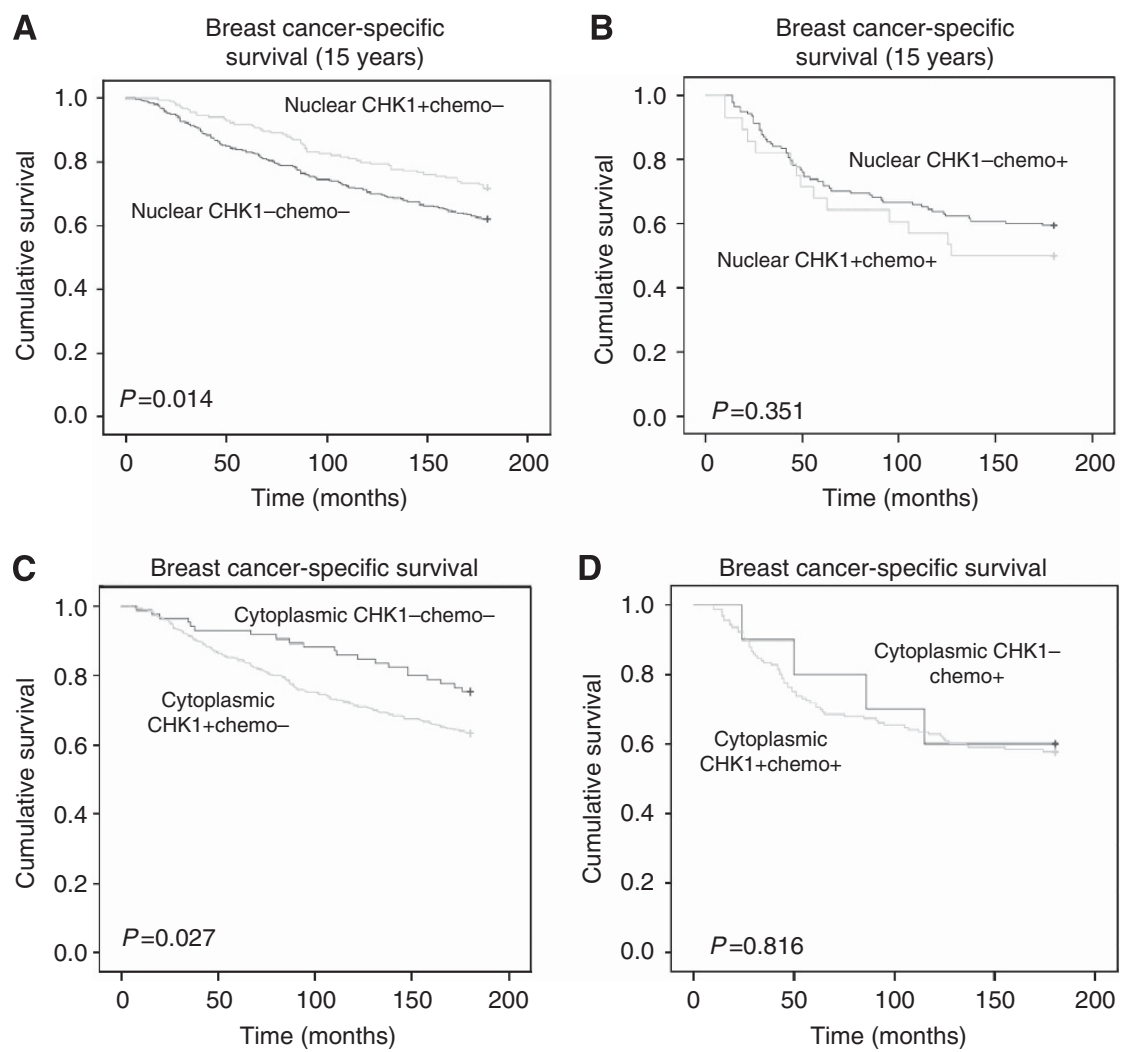

Figure 3. pCHK1 and outcome with respect to adjuvant chemotherapy. Kaplan-Meier curve of nuclear pCHK1 in patients who did not receive chemotherapy (A) or who received chemotherapy (B) with respect to BCSS at 15 years. Panels C, D represent Kaplan-Meier curve of cytoplasmic PCHK1 in patients without chemotherapy (C) or in patient who received chemotherapy (D) with respect to BCSS for 15 years. 

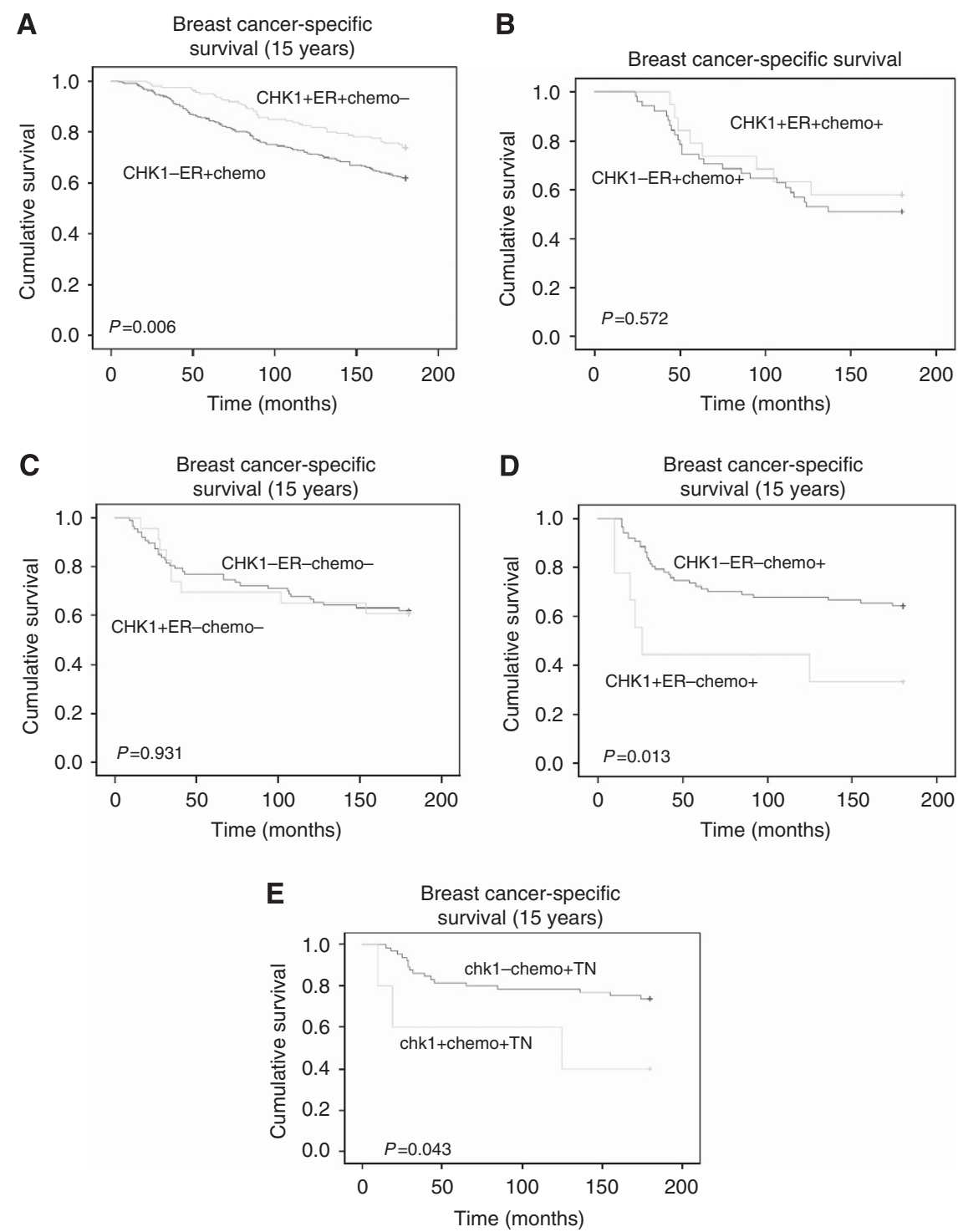

Figure 4. pCHK1 and outcome with respect to adjuvant chemotherapy in the molecular classes. Panels A, B represent Kaplan-Meier curve of nuclear PCHK1 in patients who received chemotherapy in ER + cases with respect to BCSS at 15 years, whereas C, D for ER-cases. Panel E represents Kaplan-Meier curve of nuclear PCHK1 in triple negative patients who received chemotherapy. Abbreviations: Chemo $=$ chemotherapy; $\mathrm{TN}=$ triple-negative.

ATR-dependent phosphorylation leads to rapid release of CHK1 from the nucleus to the cytoplasm (Zhang et al, 2005; Smits et al, 2006). It is also suggested that the phosphorylated form of CHK1 is able to regulate checkpoint protein events both in the cytoplasm and in the nucleus (Sørensen et al, 2005); for example, in the nucleus there will be activation of Rad51. It was also reported that mono- or diubiquitination promotes $\mathrm{CHK} 1$ nuclear exclusion (Kramer et al, 2004; Dunaway et al, 2005; Loffler et al, 2007; Wilsker et al, 2008). These results together with our findings suggest that subcellular localisation of CHK1 is important and is associated with different functions.

Regarding outcome, tumours with nuclear and cytoplasmic pCHK1 expression are associated with longer and shorter survival, respectively; however, this effect was not independent of other prognostic markers assessed in this study in the whole series.

Importantly, the association between nuclear pCHK1 and outcome was different in patients who received or did not receive CMF chemotherapy in our series. This effect was also different between ER-positive and ER-negative tumours, a finding that may reflect the known difference in DDR status between ER-positive and ER-negative BC. In the whole series, an association between positive nuclear pCHK1 expression and longer survival was found in the subgroup of patients who did not receive chemotherapy; however, no such effect was seen in patients who received chemotherapy. The same findings were maintained in the ERpositive subgroup. However, in the ER-negative and triple-negative cohorts, the opposite was identified; no association with outcome was observed in chemotherapy-naive patients, whereas in those patients who received CMF chemotherapy tumour cell expression of nuclear pCHK1 was associated with shorter survival. The association between pCHK1 expression and chemotherapy response in relation to outcome is a reflection of tumour response and was significant in the whole patient series and in the clinically important ER-negative subgroup. These results may indicate that, although positive nuclear $\mathrm{pCHK} 1$ is a marker associated with markers of good prognosis and with longer survival in chemotherapy-naive patients, in chemotherapy-treated patients it is associated with reduced survival that may reflect chemoresistance particularly in the ER-negative tumours. These results support the findings of previous studies where an association between chemoresistance and CHK1 expression has been observed (Bartek and Lukas, 2003; Kastan and Bartek, 2004; Zhou and 
Bartek, 2004; Tse et al, 2007; Verlinden et al, 2007; Dai and Grant, 2010; Merry et al, 2010; Carrassa and Damia, 2011; Ma et al, 2012). However, in this study, the outcome of patients with tumours expressing cytoplasmic pCHK1 was better when treated with CMF chemotherapy, and further investigation of the interaction between chemotherapy and CHK1 expression and its subcellular localisation is warranted ideally in a randomised clinical trial.

In conclusion, the results of this study emphasise that $\mathrm{pCHK} 1$ is an important factor in $\mathrm{BC}$, particularly with respect to DDR and proliferation status, and its subcellular localisation has an impact on the function of the protein. Nuclear pCHK1 was observed to be associated with good prognostic markers and improved survival. In contrast, cytoplasmic expression of pCHK1 is associated with markers of poor prognosis and decreased survival. KPNA2 appears to be involved in CHK1 subcellular localisation. CHK1 has a role in the response of tumours to chemotherapy and subsequently influences outcome. This effect is different between ER-positive and -negative forms of BC. Further study of activating phosphorylation of CHK1, such as phosphorylated ATR and downstream targets such as phosphorylated CDC25A, CDC25B and CDC25C, CDC25A, may help to understand the complex DDR biological processes.

\section{REFERENCES}

Agboola AO, Musa AA, Ayoade BA, Banjo AA, Anunobi CC, Deji-Agboola AM, Rakha EA, Nolan C, Ellis IO, Green AR (2014) Clinicopathological and molecular significance of Sumolyation marker (ubiquitin conjugating enzyme 9 (UBC9)) expression in breast cancer of black women. Pathol Res Pract 210(1): 10-17.

Ahn J, Urist M, Prives C (2004) The Chk2 protein kinase. DNA Rep (Amst) 3(8-9): 1039-1047.

Aleskandarany MA, Green AR, Benhasouna AA, Barros FF, Neal K, Reis-Filho JS, Ellis IO, Rakha EA (2012) Prognostic value of proliferation assay in the luminal, HER2-positive, and triple-negative biologic classes of breast cancer. Breast Cancer Res 14(1): R3.

Aleskandarany MA, Rakha EA, Ahmed MA, Powe DG, Ellis IO, Green AR (2011) Clinicopathologic and molecular significance of phospho-Akt expression in early invasive breast cancer. Breast Cancer Res Treat 127(2): 407-416.

Alshareeda AT, Negm OH, Albarakati N, Green AR, Nolan C, Sultana R, Madhusudan S, Benhasouna A, Tighe P, Ellis IO, Rakha EA (2013) Clinicopathological significance of KU70/KU80, a key DNA damage repair protein in breast cancer. Breast Cancer Res Treat 139(2): 301-310.

Alshareeda AT, Negm OH, Green AR, Nolan C, Tighe P, Albarakati N, Sultana R, Madhusudan S, Ellis IO, Rakha EA (2014) SUMOylation proteins in breast cancer. Breast Cancer Res Treat 144(3): 519-530.

Alshareeda AT, Rakha EA, Nolan CC, Ellis IO, Green AR (2012) Fatty acid binding protein 7 expression and its sub-cellular localization in breast cancer. Breast Cancer Res Treat 134(2): 519-529.

Bartek J, Lukas J (2003) Chk1 and Chk2 kinases in checkpoint control and cancer. Cancer Cell 3(5): 421-429.

Bernardi R, Liebermann DA, Hoffman B (2000) Cdc25A stability is controlled by the ubiquitin-proteasome pathway during cell cycle progression and terminal differentiation. Oncogene 19(20): 2447-2454.

Camp RL, Dolled-Filhart M, Rimm DL (2004) X-tile: a new bio-informatics tool for biomarker assessment and outcome-based cut-point optimization. Clin Cancer Res 10(21): 7252-7259.

Carrassa L, Damia G (2011) Unleashing Chk1 in cancer therapy. Cell Cycle 10(13): 2121-2128.

Chen Z, Xiao Z, Gu WZ, Xue J, Bui MH, Kovar P, Li G, Wang G, Tao ZF, Tong Y, Lin NH, Sham HL, Wang JY, Sowin TJ, Rosenberg SH, Zhang H (2006) Selective Chk1 inhibitors differentially sensitize p53-deficient cancer cells to cancer therapeutics. Int J Cancer 119(12): 2784-2794.

Dai Y, Grant S (2010) New insights into checkpoint kinase 1 in the DNA damage response signaling network. Clin Cancer Res 16(2): 376-383.
Dunaway S, Liu HY, Walworth NC (2005) Interaction of 14-3-3 protein with Chk1 affects localization and checkpoint function. J Cell Sci 118(Pt 1): 39-50.

Enomoto M, Goto H, Tomono Y, Kasahara K, Tsujimura K, Kiyono T, Inagaki M (2009) Novel positive feedback loop between Cdk1 and Chk1 in the nucleus during G2/M transition. J Biol Chem 284(49): 34223-34230.

Goto H, Izawa I, Li P, Inagaki M (2012) Novel regulation of checkpoint kinase 1: Is checkpoint kinase 1 a good candidate for anti-cancer therapy? Cancer Sci 103(7): 1195-1200.

Groth A, Lukas J, Nigg EA, Silljé HH, Wernstedt C, Bartek J, Hansen K (2003) Human Tousled like kinases are targeted by an ATM- and Chk1dependent DNA damage checkpoint. EMBO J 22(7): 1676-1687.

Harper JW, Elledge SJ (2007) The DNA damage response: ten years after. Mol Cell 28(5): 739-745.

Hirao A, Kong YY, Matsuoka S, Wakeham A, Ruland J, Yoshida H, Liu D, Elledge SJ, Mak TW (2000) DNA damage-induced activation of p53 by the checkpoint kinase Chk2. Science 287(5459): 1824-1827.

Kaneko YS, Watanabe N, Morisaki H, Akita H, Fujimoto A, Tominaga K, Terasawa M, Tachibana A, Ikeda K, Nakanishi M (1999) Cell-cycledependent and ATM-independent expression of human Chk1 kinase. Oncogene 18(25): 3673-3681.

Kastan MB, Bartek J (2004) Cell-cycle checkpoints and cancer. Nature 432(7015): 316-323.

Kramer A, Mailand N, Lukas C, Syljuasen RG, Wilkinson CJ, Nigg EA, Bartek J, Lukas J (2004) Centrosome-associated Chk1 prevents premature activation of cyclin-B-Cdk1 kinase. Nat Cell Biol 6(9): 884-891.

Loffler H, Bochtler T, Fritz B, Tews B, Ho AD, Lukas J, Bartek J, Kramer A (2007) DNA damage-induced accumulation of centrosomal Chk1 contributes to its checkpoint function. Cell Cycle 6(20): 2541-2548.

Lundgren K, Holm K, Nordenskjöld B, Borg A, Landberg G (2008) Gene products of chromosome $11 \mathrm{q}$ and their association with CCND1 gene amplification and tamoxifen resistance in premenopausal breast cancer. Breast Cancer Res 10(5): R81.

Ma CX, Cai S, Li S, Ryan CE, Guo Z, Schaiff WT, Lin L, Hoog J, Goiffon RJ, Prat A, Aft RL, Ellis MJ, Piwnica-Worms H (2012) Targeting Chk1 in p53-deficient triple-negative breast cancer is therapeutically beneficial in human-in-mouse tumor models. J Clin Invest 122(4): 1541-1552.

Merry C, Fu K, Wang J, Yeh IJ, Zhang Y (2010) Targeting the checkpoint kinase Chk1 in cancer therapy. Cell Cycle 9(2): 279-283.

Niida H, Katsuno Y, Banerjee B, Hande MP, Nakanishi M (2007) Specific role of Chk1 phosphorylations in cell survival and checkpoint activation. Mol Cell Biol 27(7): 2572-2581.

Niida H, Nakanishi M (2006) DNA damage checkpoints in mammals. Mutagenesis 21(1): 3-9.

Peng CY, Graves PR, Thoma RS, Wu Z, Shaw AS, Piwnica-Worms H (1997) Mitotic and G2 checkpoint control: regulation of 14-3-3 protein binding by phosphorylation of Cdc25C on serine-216. Science 277(5331): 1501-1505.

Puc J, Keniry M, Li HS, Pandita TK, Choudhury AD, Memeo L, Mansukhani M, Murty VV, Gaciong Z, Meek SE, Piwnica-Worms H, Hibshoosh H, Parsons R (2005) Lack of PTEN sequesters CHK1 and initiates genetic instability. Cancer Cell 7(2): 193-204.

Rakha EA, Elsheikh SE, Aleskandarany MA, Habashi HO, Green AR, Powe DG, El-Sayed ME, Benhasouna A, Brunet JS, Akslen LA, Evans AJ, Blamey R, Reis-Filho JS, Foulkes WD, Ellis IO (2009) Triple-negative breast cancer: distinguishing between basal and nonbasal subtypes. Clin Cancer Res 15(7): 2302-2310.

Rakha EA, Putti TC, Abd El-Rehim DM, Paish C, Green AR, Powe DG, Lee AH, Robertson JF, Ellis IO (2006) Morphological and immunophenotypic analysis of breast carcinomas with basal and myoepithelial differentiation. J Pathol 208(4): 495-506.

Sanchez Y, Wong C, Thoma RS, Richman R, Wu Z, Piwnica-Worms H, Elledge SJ (1997) Conservation of the Chk1 checkpoint pathway in mammals: linkage of DNA damage to Cdk regulation through Cdc25. Science 277(5331): 1497-1501.

Shen WH, Balajee AS, Wang J, Wu H, Eng C, Pandolfi PP, Yin Y (2007) Essential role for nuclear PTEN in maintaining chromosomal integrity. Cell 128(1): 157-170.

Smits VA, Reaper PM, Jackson SP (2006) Rapid PIKK-dependent release of Chk1 from chromatin promotes the DNA-damage checkpoint response. Curr Biol 16(2): 150-159.

Sørensen CS, Hansen LT, Dziegielewski J, Syljuåsen RG, Lundin C, Bartek J, Helleday T (2005) The cell-cycle checkpoint kinase Chk1 is required for mammalian homologous recombination repair. Nat Cell Biol 7(2): 195-201. 
Tapia-Alveal C, Calonge TM, O’Connell MJ (2009) Regulation of chk1. Cell Div 4: 8.

Thompson R, Eastman A (2013) The cancer therapeutic potential of Chk1 inhibitors: how mechanistic studies impact on clinical trial design. Br J Clin Pharmacol 76(3): 358-369.

Tse AN, Carvajal R, Schwartz GK (2007) Targeting checkpoint kinase 1 in cancer therapeutics. Clin Cancer Res 13(7): 1955-1960.

Verlinden L, Vanden Bempt I, Eelen G, Drijkoningen M, Verlinden I, Marchal K, De Wolf-Peeters C, Christiaens MR, Michiels L, Bouillon R, Verstuyf A (2007) The E2F-regulated gene Chk1 is highly expressed in triple-negative estrogen receptor/progesterone receptor/HER-2 breast carcinomas. Cancer Res 67(14): 6574-6581.

Walworth N, Davey S, Beach D (1993) Fission yeast chk1 protein kinase links the rad checkpoint pathway to cdc2. Nature 363(6427): 368-371.

Wang J, Han X, Feng X, Wang Z, Zhang Y (2012) Coupling cellular localization and function of checkpoint kinase 1 (Chk1) in checkpoints and cell viability. J Biol Chem 287(30): 25501-25509.

Wilsker D, Petermann E, Helleday T, Bunz F (2008) Essential function of Chk1 can be uncoupled from DNA damage checkpoint and replication control. Proc Natl Acad Sci USA 105(52): 20752-20757.

Xu N, Libertini S, Black EJ, Lao Y, Hegarat N, Walker M, Gillespie DA (2012) Cdk-mediated phosphorylation of Chk1 is required for efficient activation and full checkpoint proficiency in response to DNA damage. Oncogene 31(9): 1086-1094.
Yarden RI, Pardo-Reoyo S, Sgagias M, Cowan KH, Brody LC (2002) BRCA1 regulates the G2/M checkpoint by activating Chk1 kinase upon DNA damage. Nat Genet 30(3): 285-289.

Yin Y, Shen WH (2008) PTEN: a new guardian of the genome. Oncogene 27(41): 5443-5453.

Zaugg K, Su YW, Reilly PT, Moolani Y, Cheung CC, Hakem R, Hirao A, Liu Q, Elledge SJ, Mak TW (2007) Cross-talk between Chk1 and Chk2 in double-mutant thymocytes. Proc Natl Acad Sci USA 104(10): 3805-3810.

Zhang YW, Otterness DM, Chiang GG, Xie W, Liu YC, Mercurio F, Abraham RT (2005) Genotoxic stress targets human Chk1 for degradation by the ubiquitin-proteasome pathway. Mol Cell 19(5): 607-618.

Zhao H, Piwnica-Worms H (2001) ATR-mediated checkpoint pathways regulate phosphorylation and activation of human Chk1. Mol Cell Biol 21(13): 4129-4139.

Zhou BB, Bartek J (2004) Targeting the checkpoint kinases: chemosensitization versus chemoprotection. Nat Rev Cancer 4(3): 216-225.

This work is published under the standard license to publish agreement. After 12 months the work will become freely available and the license terms will switch to a Creative Commons AttributionNonCommercial-Share Alike 4.0 Unported License. 